Visuaalisesti kirja kutsuu koskettamaan ja ottamaan käteensä. Se on tyylikäs ja puhutteleva. Kirjan kuvitus kertoo tarinoiden päähenkilöistä, heidän tavallisesta arjestaan, kauhistelematta tai kaunistelematta. Kuvat vahvistavat kokemusta, jonka tarinat lukijalleen välittävät. Kun kirjaan koskee siihen jää heti koukkuun. Kirjan kuvat ovat koukuttavia ja puhuttelevia, mutta sama vaikutus on myös tarinoilla. Yksi syy tarinoiden koukuttavuuteen on se, että ne ovat suhteellisen lyhyitä ja kompakteja. Niissä ei jäädä jaarittelemaan eikä piehtaroimaan liikaa yksityiskohdissa. Tarinat on tietysti alun perin kerrottu jollakin muulla kielellä kuin suomeksi, mutta tekstien käännökset toimivat erinomaisesti.

Kaikki tarinat päättyvät karkotettujen lähtö-/kotimaahan - siis siihen, kuinka tarinoiden päähenkilöt ovat karkotettuina lähtömaissaan. Minun on pakko uskoa, että näissä tarinoissa on avoimet loput. Kuten tutkijat Jukka Könönen ja Niina Vuolajärvi kirjan loppuyhteenvedossaan toteavat:

"Onkin mahdollista, että myös kirjan henkilöt pyrkivät palaamaan takaisin Eurooppaan. Toivomme, että onni on heidän puolellaan seuraavalla kerralla, kun he luovivat eurooppalaisen maahanmuuttobyrokratian karikoissa" (s. 169).

Itse suorastaan toivon, että tarinoiden päähenkilöillä on mahdollista jatkaa yrittämistä Euroopan muurien sisäpuolelle! Toivon, että seuraavalla kerralla Christiana, Hunar ja Lana osaavat kertoa turvapaikkakuulustelussa tarpeeksi selkeästi, millaisessa vaarassa he kotimaassaan ovat. Lisäksi toivon, että
Euroopassa ei enää hajotettaisi yhtään perhettä eikä avioliittoa turvapaikkaprosessin aikana. Ja viimeiseksi kysyn, miksi meille eurooppalaisille hyvinvointivaltioille ei kelpaa EU:n ulkopuolelta tuleva työntekijäksi, opiskelijaksi ja naapuriksi. Miksi olemme rakentaneet itsellemme linnoituksen, jota muut saavat vain katsella ulkoapäin?

\section{KOHTI AITOJA KOHTAAMISIA}

Sanna Ryynänen, FT, sosiaalipedagogiikan ma. yliopistonlehtori, Itä-Suomen yliopisto

Hiitola, Johanna, Anis, Merja \& Turtiainen, Kati (toim.): Maahanmuutto, palvelut ja hyvinvointi. Kohtaamisissa kehittyviä käytäntöjä. Vastapaino, Tampere. $2018,243 \mathrm{~s}$.

Millaista tukea ja millaisia palveluita maahanmuuttotaustaiset ihmiset kokevat tarvitsevansa? Miten erilaisissa palveluissa kohdataan maahanmuuttotaustaisia ihmisiä ja miten heidän tilanteisiinsa niissä vastataan? Kysymykset johdattavat kirjaan Maahanmuutto, palvelut ja hyvinvointi, jonka ovat toimittaneet Johanna Hiitola, Merja Anis ja Kati Turtiainen. Kirjan keskeinen teema on institutionaalisissa ja ammatillisissa suhteissa tapahtuva kohtaaminen. Se täsmentyy erityisesti sen tarkasteluksi, vahvistavatko vai vaikeuttavatko palvelujärjestelmässä toteutuvat kohtaamiset maahanmuuttajien osallisuutta ja toimijuutta.

Kirjan yhdeksää artikkelia yhdistää näkemys siitä, että osallisuus ja toimijuus 
ovat olennaisia kotoutumisen ja sen myötä hyvinvoinnin rakentajia. Vaikka artikkeleissa lähestytään osallisuuden ja toimijuuden teemoja hieman eri tavoin painottaen, kirjan läpileikkaavaksi eetokseksi voi tunnistaa ensimmäisessä artikkelissa kuvatun kriittisen autonomian tukemisen tavoitteen. Kriittisen autonomian näkökulma ohjaa näkemään kotoutumisen prosessissa elävät maahanmuuttajat kuuliaisten uuteen yhteiskuntaan asettujien sijaan paikastaan ja tilanteestaan neuvottelevina arjen kansalaisina, joissa yhdistyy kyvykkyys ja erityinen haavoittuvuus.

Valtaosa artikkeleista nojautuu empiirisiin tutkimuksiin, joissa aineistoa on kerätty joko palvelujärjestelmän ammattilaisilta, maahanmuuttajilta tai molemmilta. Tutkimusotteet vaihtelevat haastatteluista etnografiaan. Aineistojen analyysissä on hyödynnetty perinteisen sisällönanalyysin lisäksi myös metaforaja kategoria-analyysiä.

Artikkelit on jaettu temaattisesti kolmeksi kokonaisuudeksi: Osallisuutta järjestelmän ehdoilla, Kohtaamisissa muotoutuvia merkityksiä ja toimijuuksia sekä Hyvinvoinnin rakentuminen suhteissa. Jaottelu jäsentää ja jäntevöittää artikkelien moninäkökulmaista kokonaisuutta. Sen vuoksi temaattisen jäsennyksen olisikin toivonut kulkevan läpi kirjan vähintäänkin väliotsikoina tai sivujen ylätunnisteina. Nyt jaottelu näkyy jostain syystä ainoastaan kirjan sisällysluettelossa. Lukukokemus olisi myös saattanut jäsentyä selkeämmäksi, jos artikkelien järjestys olisi ollut osin toinen. Nyt etenkin kirjan alkupuoli tuntuu temaattisesti hieman poukkoilevalta.
Maahanmuuttajille suunnattujen palvelujen, kohtaamisen ja hyvinvoinnin teemoihin liittyvät ilmeiset näkökulmat, kuten kuntien ja järjestöjen tarjoamat kotoutumispalvelut ja tulkkauspalvelut, yhdistyvät kirjassa myös yllättävämpiin tulokulmiin, kuten rekisteröinnin ja tilastoinnin käytäntöihin. Kohtaamisen teema virittyy näin muistutukseksi myös siitä, että monille kansalaisille ja viranomaisille valtiollinen tilastotieto on keskeinen "kohtaaminen" maahanmuuttajien kanssa. Riikka Homasen ja Marja Alastalon artikkeli Perhesuhteet ulkomaalaisten rekisteröinnissä ja tilastoinnissa purkaa ansiokkaasti sitä normaaliutta ja itsestäänselvyyttä, joka tilastoihin ja rekistereihin, samoin kuin niitä tuottaviin käytäntöihin vähintäänkin arkiajattelussa yhdistyy. Kirjoittajat muistuttavat, että vaikkapa perhetilastot eivät ole neutraalia faktaa vaan ne myös organisoivat sosiaalisia suhteita tavalla, jolla on konkreettisia vaikutuksia maahanmuuttajaperheiden elämään.

Mulki Al-Sharmani, Sanna Mustasaari ja Abdirashid A. Ismail osoittavat moskeijoiden perheriitojen sovittelutyötä käsittelevässä artikkelissaan puolestaan sen, että maahanmuuttajat saattavat käyttää palveluita, jotka eivät nykyisellään välttämättä kohtaa keskenään. Kirjoittajat esittävät, että eri toimijoiden välistä keskusteluyhteyttä tulisikin vahvistaa esimerkiksi pysyviä yhteydenpitomekanismeja perustamalla. Tämä koskee niin valtiollisen palvelujärjestelmän ja uskonnollisten järjestelmien, kuten moskeijoiden, toimintojen keskinäistä koordinointia, kuin laajasti koko kolmannen sektorin toimintaa. 
Kirjan artikkeleissa tulee näin ollen eri tavoin esiin se, että pohtiessamme maahanmuuttajien (ja kenen tahansa) kohtaamisen käytäntöjä, ei riitä, että keskitytään yksinomaan konkreettisiin kohtaamisen tilanteisiin, tapoihin ja käytäntöihin, vaan huomio tulee kohdistaa myös rakenteisiin, samoin kuin palvelujärjestelmässä tapahtuvia kohtaamisia kehystävään maahanmuuttajien arkeen. Kohtaamisilla on siis aina rakenteelliset edellytyksensä, ehtonsa ja esteensä. Kohtaamisen osapuolet myös tuovat mukanaan eletyn elämänsä ja kokemuksensa, mukaan lukien mahdolliset traumansa. Maahanmuuttajilla tämä tarkoittaa paitsi monesti raskasta ja traumatisoivaa elämänhistoriaa myös arjessa toistuvaa rodullistavaa kategorisointia ja usein negatiivista stereotypisointia.

Kirja muistuttaakin, että kohtaamisiin saattaa latautua paljon enemmän, kuin mitä niissä on näennäisesti läsnä. Lotta Kokkonen esimerkiksi kuvaa vuorovaikutuksessa toteutuvaa sosiaalista tukea käsittelevässä artikkelissaan, että muiden sosiaalisten suhteiden vähyys tai puute saattaa kohdistaa sosiaalisen tuen tarpeet nimenomaan palvelujärjestelmässä kohdattaviin ihmisiin. Tällöin esimerkiksi kohtaamiseen viranomaisen kanssa saattaa kasautua odotuksia, joita ei osata ajatella tai huomioida, tai joihin viranomainen ei roolinsa puitteissa koe pystyvänsä vastaamaan.

Maahanmuuttotaustaisten ihmisten moninaisuus ja yksilölliset tilanteet ja toimijuudet saatetaan myös sivuuttaa eri tavoin. Johanna Hiitola ja Marja Peltola alleviivaavat viranomaisten ja maahanmuuttotaustaisten vanhempien kohtaamisia käsittelevässä artikkelissaan toiseuttavien ja universalismia korostavien puhetapojen ongelmallisuutta. Toiseuttavat puhetavat nojaavat stereotypisoiviin kategorisointeihin, joissa toinen "tiedetään" jo ennalta vieraaksi ja erilaiseksi. Eroja häivyttävät puhetavat piilottavat puolestaan yksilöt ja yksilölliset erot. Tiina Sotkasiiran metafora-analyysi syrjäseutujen kotouttamispalveluista puolestaan osoittaa, että maahanmuuttajataustaisten ihmisten olemassa oleva kyvykkyys tulee usein ohitetuksi sen sijaan, että se tunnistettaisiin ja sitä tuettaisiin. Näissä kahdessa artikkelissa kiteytyy keskeinen haaste, joka palvelujärjestelmää rasittanee laajemminkin: ihmisen unohtaminen.

Kohtaamattomuuden kokemusten vastavoimaksi kirjassa nostetaan toisen yksilöllisyyden ja erityisyyden huomioiva ja sitä kunnioittava kohtaaminen - eli kuuntelu ja dialogi. Artikkelista toiseen toistuu ajatus yksilön aidon kohtaamisen, yksityiskohtia havaitsevan herkkyyden sekä tunnustuksen antamisen ja saamisen merkityksellisyydestä. Nämä perustavanlaatuiset ihmistyön periaatteet näyttäytyvät ajoittain suorastaan radikaaleina, kun niitä suhteuttaa moniin jotakuinkin vastakkaisia kokemuksia kuvaaviin tutkimustuloksiin - joskin tutkimukset tuovat esiin hyviäkin kokemuksia palvelujärjestelmäkohtaamisista. Tunnustuksen teemoja käsitellään erityisen ansiokkaasti Kati Turtiaisen ja Jassin Rezain artikkelissa. Se yhdistää henkilökohtaisen kokemuksen ja teoreettisen analyysin tavalla, jota soisi näkevän maahanmuutto- ja miksei missä tahansa muussakin tutkimuksessa enemmän. Artikkeli päästää lukijan konkreettisesti yleistävien kategorioi- 
den taa nostaessaan esiin yhden ihmisen elämänpolun ja asettaessaan sen dialogiin Axel Honnethin tunnustuksen teorian kanssa. Samalla jäsentyvät laadulliset vaatimukset, joita viranomaisten ja maahanmuuttajien kohtaamisissa tulisi noudattaa: huolenpito, kunnioittaminen ja sosiaalinen arvostaminen.

Kaikkinensa kirja antaa yleisluontoisia suuntaviivoja osallisuutta ja toimijuutta tukevan maahanmuuttajatyön käytännöille. Kirjassa korostuu näkemys siitä, että kotoutuminen tulisi nykyistä vahvemmin ymmärtää mahdollisuutena tehdä omaa elämää koskevia valintoja, siis kotoutujien kyvykkyyden tunnustamisena ja siihen nojautuvan kriittisen autonomian tukemisena. Kirja myös osoittaa, monialaiseen ja -näkökulmaiseen tutkimusmateriaaliin perustuen, että hyvin perustavanlaatuiset toisen ihmisen näkemiseen ja kohtaamiseen liittyvät käytännöt ovat maahanmuuttajatyössä usein hukassa.

Kuten artikkelikokoelmissa aina, osa artikkeleista istuu kokonaisuuteen toi- sia paremmin. Lukukokemus onkin ajoittain hieman hypähtelevä, kulkien ajatuksia avaavista oivaltavista näkökulmista ja ansiokkaista analyyseistä hienoisiin suvantokohtiin ja teemoihin, joiden merkitystä kirjan kokonaisuudessa saa hieman hakea. Tämänkaltaisen artikkelikokoelman luonteeseenkin toki kuuluu, että luettavaksi voi poimia erityisesti omaa työtä tai kiinnostuksenaluetta sivuavat tekstit. Kiireisen lukijan shortlistiksi ehdottaisin Sotkasiiran, Hiitolan ja Peltolan, Rautavuoman ja Turtiaisen sekä Turtiaisen ja Rezain artikkeleja. Niissä tiivistyy monia sellaisia näkökulmia kohtaamisesta, osallisuudesta ja toimijuudesta, joiden toivoisi löytävän tiensä maahanmuuttajatyöhön ja sen kohtaamisen käytäntöihin. Sotkasiiran sanoin, "kotouttamiskeskustelun yleiset teemat - puhe kotoutumisen tavoitteista, keinoista ja resursseista - tarvitsevat rinnalleen hienosyisempää pohdintaa, joka lähtee liikkeelle kotoutujien omista käytännöistä, tavoitteista ja haluista”. 